\title{
Can Ranch Owners Include the Ranch in an Investment Portfolio?
}

\section{Reducing ranching financial risk can be achieved by diversification of assets.}

\section{By Jerry M. Hawkes, James D. Libbin, and Jeremy D. Kohler}

$\mathrm{P}$ roduction agriculture is a capital-intensive venture that bears many elements of uncertainty. Producers must tolerate a substantial amount of risk and combat many challenges within their preferred livelihood. Many ranchers are constrained by limited income and free cash flow, although some have built equity with the appreciation of land values. Land is an inflation hedge and builds wealth over the lifetime of the landowner. However, that wealth accumulation cannot be spent without selling the land itself. Some successful producers, especially those who inherit land or otherwise do not have to repay land notes, may expand their operations or consider strategies to diversify and protect their interests and lifestyle. If ranchers are able to generate investable funds, what options exist for them?

Historically, agricultural producers have not considered diversification in the same manner as a typical financial investor. Diversification may be defined as spreading risk among many assets to offset changes in markets that will not likely react similarly to economic or financial news and phenomena (Brigham and Ehrhardt 2002). Ranchers often look at diversification as changing their calf retention system, rotational system, livestock breeds, or even purchasing another ranch several miles away for geographic diversification. None of these actions fits the definition of diversification from a purely financial perspective; some may even increase risk. Producers are still subject to the same uncontrollable market forces and weather conditions if they expand within the same class of livestock or within the same general geographic area. Expanding geo- graphically may spread fixed costs over more acres or sections and generate larger gross returns. However, expanding may lead to inefficiencies in labor and managerial resources, increase mileage on equipment, and ultimately increase fixed costs. Expansion may increase rather than reduce risk. So how should a rancher truly diversify? Ranches can be thought of as assets within an overall portfolio; ranchers should also give attention to the concept of diversification in their operations and consider diversification approaches beyond the ranching enterprise itself.

This paper will not propose that producers sell the ranch and invest the proceeds entirely in the stock market or any other investment market. Rather, ranchers should consider opportunities to increase overall portfolio value by investing a portion of operating profit in financial assets (such as corporate stocks or mutual funds) to diversify. Diversifying in this manner may provide a ranch owner/investor with greater returns on investment opposed to production agriculture alone. This might allow a rancher to continue with his or her chosen lifestyle in the agricultural environment and to maintain control of the primary real asset, which is the ranch.

\section{How the Problem Was Approached}

The purpose of this paper is to show how ranchers might use the financial securities markets to diversify their ranch operations. In other words, we hope to encourage ranchers to connect their ranch investment with their financial investments. Our approach is to provide an example-an example group of securities and an example ranch - to see how ranch 
ownership and securities markets might be used together. Considering the ranch and securities together may seem to be a big step, but we will show that there can be great advantages to analyzing ranch income and financial securities as one unit-a portfolio.

The rest of this paper will attempt to make this connection. First, we lay out the financial principles. Many ranchers already own stocks and bonds either directly or indirectly (through mutual funds, IRAs, or retirement funds). Ranchers and their brokers should repeat our process for individual ranch income patterns and stock preferences. We simply argue that ranch income should be an integral part of the process.

The last part of the paper shows an example ranch. We actually started with 5 representative ranch models representing different geographic regions, range types, and livestock classes throughout New Mexico. Then we collected risk and return data on 50 publicly held agricultural companies (Value Line Investment Survey 1989-2002), a money market fund, and an agriculturally oriented mutual fund.

\section{Investment Objectives}

The nature of each investor and the objectives of investors may differ, but Markowitz (1959) identifies two objectives common to all investors:

- They want returns to be high. The appropriate definition of return may vary from investor to investor. But, in whatever sense is appropriate, they prefer more of it to less.

- They want this return to be dependable, stable, and not subject to uncertainty; that is, they prefer certainty to uncertainty.

A good portfolio is more than a large combination of securities. It is balanced as a whole to provide financial protection opportunities. Investors should build portfolios tailored to their individual needs. Developing portfolios begins with information on individual assets and ends as a mixed whole.

Risk can be a difficult concept to grasp; there has not been universal agreement on how to define and measure it in a portfolio context. Efficient portfolios are defined as those combinations of assets that

\section{Diversifiable and Nondiversifiable Risk}

Risk can be separated into both market (nondiversifiable or systematic) risk and standalone (diversifiable or nonsystematic) risk. Any asset's risk is equal to its systematic risk plus its nonsystematic risk. Diversifiable risk is affected by factors associated with a particular asset and can be nearly eliminated by diversification. Market risk stems from factors such as inflation, recessions, business cycles, or interest rates and cannot be eliminated by diversification. All investments have both nonsystematic and systematic risk. Since a large part of nonsystematic risk can be eliminated by diversification, the rational investor will only be concerned with market risk. Therefore, the relevant risk on an investment is its contribution of risk to a well-diversified portfolio.

together provide the highest expected return for any degree of risk or the lowest degree of risk for any expected return. Unreachable (or infeasible) portfolios are those portfolios that cannot be reachedthere is no combination of assets that can show the risk and return - and must be eliminated quickly to leave only the reachable ones (there is a combination of various assets that can reach desired risk/return levels) for further analysis. The efficient portfolios are found among the reachable opportunities. We must first determine which of the reachable portfolios are efficient and then choose the single best portfolio for the investor.

The Single Index Model (SIM) was developed by Sharpe in 1963 (Sharpe 1970) and builds on earlier work by Markowitz called the Capital Asset Pricing Model (CAPM). The SIM allowed Markowitz's work to be applied to real-world portfolios with actual equity securities and actual investors.

Portfolio management of agricultural production units could be thought of as simply a special case of investment portfolio management. We assume two basic ideas:

- Ranchers wish to maximize returns from their total portfolio (ranch plus investment). 


\section{Beta}

The primary conclusion of the CAPM is that the relevant risk of an individual investment is its contribution of risk to a well-diversified portfolio. The benchmark for a well-diversified portfolio is the market portfolio, which would contain all securities. Therefore, the relevant risk of an individual investment is the amount of risk that it contributes to the market portfolio. We refer to this relevant risk as the beta coefficient. The beta coefficient, denoted by bi, is defined as

$$
b_{i}=\left(\frac{\sigma_{i}}{\sigma_{M}}\right) r_{i M}
$$

where

$$
\begin{aligned}
b_{i}= & \text { beta coefficient of the ith security, } \\
\sigma_{i} & =\text { standard deviation of expected returns of the ith security } \\
\sigma_{M}= & \text { standard deviation of expected returns of the market, } \\
r_{i M}= & \text { correlation between the ith security's expected return and the expected return } \\
& \text { on the market. }
\end{aligned}
$$

This suggests that a stock with a high standard deviation will tend to have a high beta. This is logical since a stock with high stand-alone risk will contribute more risk to a portfolio. Also, a stock with high correlation to the market will have a large beta coefficient. This is also fitting since high correlation means that diversification does little to help, and the stock contributes a lot of risk to the portfolio. Accordingly, the tendency of a security to move up and down with the market is measured by its beta coefficient. An average security is defined as one that tends to move along with the market as defined by an index or some other market proxy. So an average stock will, by definition, have a beta coefficient of 1.0 , which means that the security moves concurrently with the market. Securities with betas larger than 1.0 are said to be more risky, while securities with betas less than 1.0 are said to contribute less risk to the portfolio. Thus, since beta is a measure of a security's contribution of risk to a portfolio, it is theoretically the correct measure of risk.

- The ranch will not be sold in order to invest in another investment alternative.

A more exhaustive (some may say exhausting) review of portfolio risk research related to mixedasset portfolios-those that include financial instruments and real estate - can be found in Libbin et al (2004).

\section{Enterprise Cost and Return Estimates}

Five of the 24 New Mexico State University representative ranch models were originally selected to provide the example for this study over the 13-year period from 1989 through 2001 (Torell et al 2000). To determine the amount of available disposable cash income, it was necessary to remove all noncash expenses including depreciation, value of owner-op- erator labor and management, and cost of capital from the enterprise cost and return estimates.

\section{Ranch Cash Flow Models}

Once the annual net cash income was determined for the ranch model, a detailed spreadsheet was developed to include different financial strategies for using the amount of cash that exceeded the level necessary to continue production. A rancher wishing to duplicate this paper's approach on his or her own ranch would build a similar spreadsheet using actual ranch numbers. Key elements of the models were the following:

- Each strategy was evaluated over the period from 1989 through 2001.

- Spreadsheets were used to observe owner's equity, which can be called portfolio value. 
- Each spreadsheet included a balance sheet, amortization schedule, income tax calculations, and cash flow summary.

- Various financial scenarios were built and articulated year to year from 1989 to 2001 to observe and compare the effect of each strategy on portfolio value with various debt loads.

- Ranch betas for use in the SIM were calculated using the S\&P 500 as a market proxy.

A land value index was created using New Mexico land value estimates published by the US Department of Agriculture. The beginning 1989 total ranch values were indexed annually to show changes in land market values. Land values were included in the balance sheet and, along with land interest rates, were necessary for developing the amortization schedule. The values of dwellings, buildings and fences, equipment, and livestock were all included in the balance sheet. The balance sheet was developed to determine owner's equity or portfolio value. Owner's equity is simply total assets minus total liabilities.

Key elements in our modeling approach need to be duplicated for or adapted to each real ranch situation: ${ }^{1}$

- Every ranch needs some working capital. Consequently, each ranch model assumed that beginning cash was $\$ 10,000$.

- At least \$10,000 cash was maintained for operating purposes every year even if it had to be borrowed in the short term.

- Operating loans were taken only if ending cash from the previous year was less than $\$ 10,000$.

- Land, equipment, and livestock were purchased at the beginning of 1989 .

- All or a portion of the purchase price for both land and equipment had to be borrowed.

- The amortization schedule also shows the principal and interest portion for annual equipment replacement.

- Income from investments came from the cash flow summary and was calculated as the total number of shares held of each investment times the annual dividends paid per share.

${ }^{1}$ Additional modeling details and a complete example spreadsheet may be obtained from the authors.
- Depreciation and interest expense were deducted from net cash income to derive net ranch profit.

- Standard deduction, personal exemptions, self-employment tax, and personal income tax were all calculated using each year's appropriate federal tax laws to determine each year's total tax liability.

- The cash flow summary must include all cash flows received and all cash flows paid out in order to calculate annual net cash flow.

- Return on equity was calculated by dividing net income by owner's equity and is the percentage return use to calculate each ranch beta. This was calculated on both a cash and a market basis.

- The market basis includes not only net income as return but also the amount of land appreciation from the previous year.

- Family living withdrawals must be included as a cash use.

- Business principal was removed from net income to determine net cash flow.

- Beginning cash plus net cash flow determined ending cash, which established the amount of cash to be utilized for each alternative financial strategy.

\section{Financial Strategies}

The goal of the entire process was to maximize ending net worth; 9 financial strategies were evaluated against that standard. Each strategy invested the cash not needed for production, family living, or taxes.

- Pay down debt. Any excess cash generated by the ranch is used to repay land principal beyond annual obligation.

- Retain cash. Any extra cash was retained and carried forward to the next year.

- Money market investment. Excess cash purchased shares of the Fidelity Select Money Market fund.

- Mutual fund investment. Excess cash was allocated to the Fidelity Select Food \& Agriculture mutual fund. This mutual fund is the only specifically agriculturally oriented mutual fund. It also began in 1985 and was traded during all years considered in this study.

- Naive portfolio of stocks. A naive portfolio is a collection of stocks that have not been evaluated 
Table 1. Naive portfolio of stocks (1989-2001)

\begin{tabular}{|c|c|c|c|c|c|}
\hline Sector & Firm & Symbol & Mean return & $\begin{array}{l}\text { Standard } \\
\text { deviation of } \\
\text { returns }\end{array}$ & Beta \\
\hline \multirow[t]{7}{*}{ Paper and forest products } & Boise Cascade Corp. & $\mathrm{BCC}$ & $3.8 \%$ & $10.0 \%$ & 1.20 \\
\hline & Glatfelter & GLT & $7.6 \%$ & $13.9 \%$ & 0.75 \\
\hline & International Paper & IP & $4.0 \%$ & $11.7 \%$ & 1.00 \\
\hline & Longview Fibre & LFB & $6.9 \%$ & $10.7 \%$ & 0.90 \\
\hline & Potlatch Corp. & $\mathrm{PCH}$ & $6.5 \%$ & $4.9 \%$ & 0.90 \\
\hline & Wausau-Mosinee Paper Corp. & WMO & $8.6 \%$ & $5.2 \%$ & 1.00 \\
\hline & Weyerhaeuser Corp. & WY & $5.8 \%$ & $12.9 \%$ & 1.05 \\
\hline \multirow[t]{2}{*}{ Chemical } & Dupont & DD & $6.4 \%$ & $19.9 \%$ & 1.00 \\
\hline & Norsk Hydro & ADR & $5.5 \%$ & $14.9 \%$ & 0.75 \\
\hline \multirow[t]{2}{*}{ Machinery } & Caterpillar Inc. & CAT & $8.7 \%$ & $10.1 \%$ & 1.15 \\
\hline & Deere \& Co. & $\mathrm{DE}$ & $8.2 \%$ & $12.3 \%$ & 1.05 \\
\hline \multirow[t]{22}{*}{ Food processing } & Archer Daniels Midland & ADM & $11.4 \%$ & $17.1 \%$ & 0.70 \\
\hline & Campbell Soup & $\mathrm{CPB}$ & $8.8 \%$ & $7.5 \%$ & 0.65 \\
\hline & Dole Food Co., Inc. & DOL & $5.9 \%$ & $7.2 \%$ & 0.75 \\
\hline & Dreyer's Grand Ice Cream & DRYR & $14.4 \%$ & $9.7 \%$ & 0.85 \\
\hline & Heinz (H.J.) Co. & HNZ & $9.5 \%$ & $5.2 \%$ & 0.55 \\
\hline & Hershey Foods & HSY & $11.7 \%$ & $6.0 \%$ & 0.60 \\
\hline & Hormel Foods & HRL & $6.8 \%$ & $5.2 \%$ & 0.55 \\
\hline & International Multifoods Corp. & IMC & $4.2 \%$ & $6.4 \%$ & 0.60 \\
\hline & Kellog Co. & $\mathrm{K}$ & $12.7 \%$ & $7.4 \%$ & 0.60 \\
\hline & Lance, Inc. & LNCE & $9.8 \%$ & $4.7 \%$ & 0.55 \\
\hline & McCormick \& Co. & MKC & $10.0 \%$ & $4.3 \%$ & 0.50 \\
\hline & Pilgrim's Pride Corp. & $\mathrm{CHX}$ & $11.5 \%$ & $15.3 \%$ & 0.70 \\
\hline & Sara Lee Corp. & SLE & $7.4 \%$ & $5.7 \%$ & 0.60 \\
\hline & Sensient Technologies & SXT & $4.6 \%$ & $9.9 \%$ & 0.65 \\
\hline & Smithfield Foods Inc. & SFD & $14.0 \%$ & $20.8 \%$ & 0.90 \\
\hline & Smucker (J.M.) Co. & SJM & $9.4 \%$ & $9.5 \%$ & 0.60 \\
\hline & Tasty Baking Co. & TBC & $0.2 \%$ & $16.2 \%$ & 0.45 \\
\hline & Tootsie Roll Industries & TR & $12.8 \%$ & $9.4 \%$ & 0.65 \\
\hline & Tyson Foods Inc. & TSN & $9.9 \%$ & $13.1 \%$ & 0.80 \\
\hline & Unilever N.V. & UN & $6.8 \%$ & $11.0 \%$ & 0.75 \\
\hline & Unilever PLC & $\mathrm{UL}$ & $6.8 \%$ & $10.8 \%$ & 0.75 \\
\hline & Wrigley Co. & WWY & $15.7 \%$ & $4.7 \%$ & 0.75 \\
\hline
\end{tabular}


Table 1. Continued

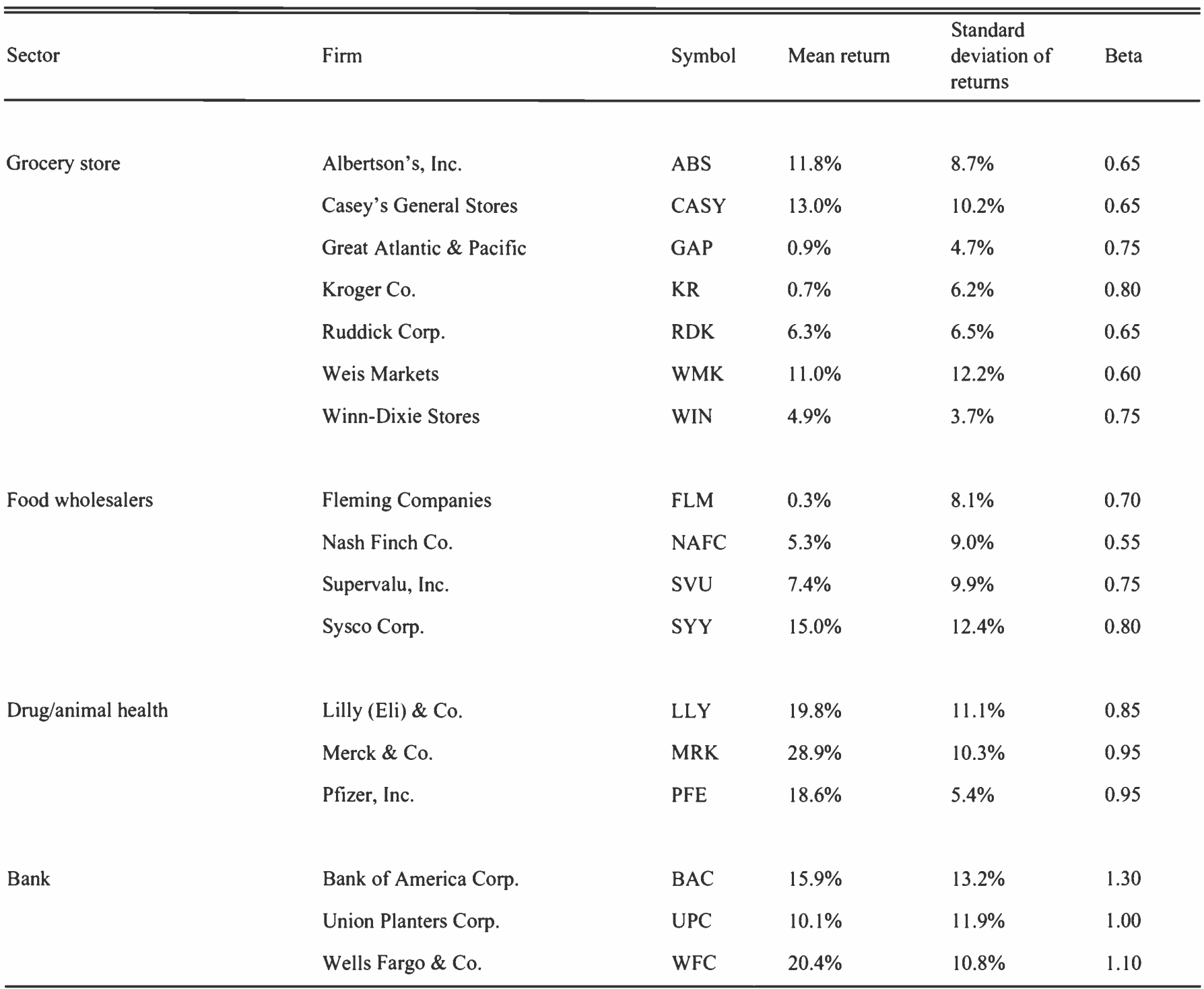

based on any risk or return measures or any other statistical analysis or performance criteria; it is simply a selection (sample) of stocks from a population. Information on 50 publicly traded agricultural firms was collected from the Value Line Investment Survey (1989-2002). From these data, annual total return was calculated for each stock, which included both dividends and capital gains or losses. All available cash was divided equally to purchase shares of stock of each firm; that is, $2 \%$ of each year's excess cash was invested in each firm. Round lot purchasing was ignored. Table 1 lists all firms used in the construction of the naive portfolio and includes the calculated mean return and standard deviation of returns of each stock throughout the entire period of the analysis. The beta coefficients are the Value Line reported betas.

- Efficient portfolios of stocks. Efficient portfolios provide the highest return for any degree of risk or the lowest degree of risk for any return. With that in mind, an efficient set of stocks was chosen from the available set of 50 stocks. The efficient frontier included a set of 5 stocks that dominated all other stocks since they offered a higher return for any degree of risk or a lower degree of risk for any return. Table 2 lists each efficient stock and gives the mean return and the risk measure (measured by standard deviations of returns) of each stock. Figure 1 shows the risk 


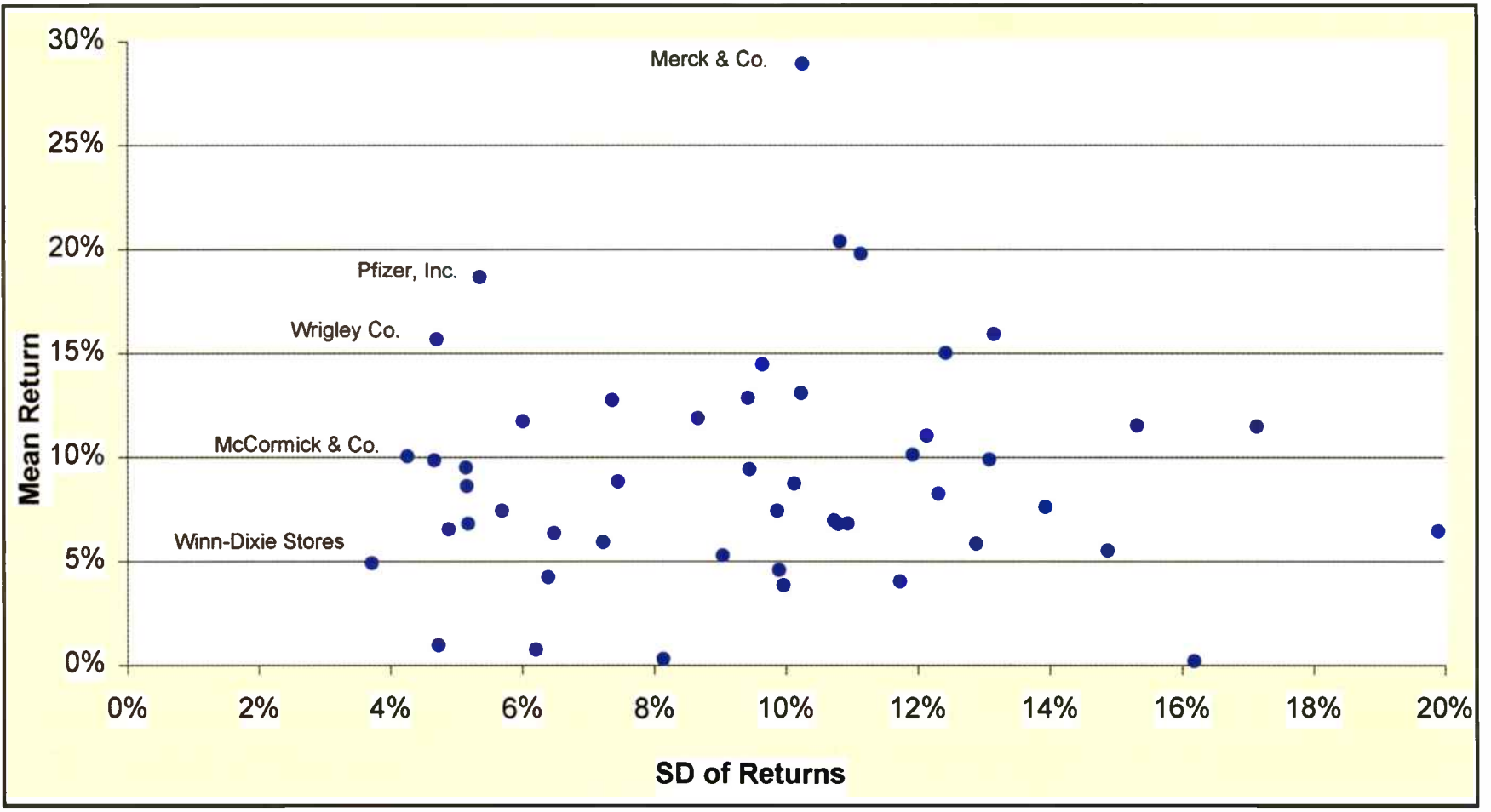

Figure. 1. Efficient frontier (1989-2001).

and return profile for all 50 stocks and labels the efficient set. Given that the efficient set was made up of 5 stocks, all excess cash was divided equally and invested in each of those individual stocks.

- Input corporation stock. Investing in input firms consisted of purchasing shares of stock of those firms that produce products or provide services that a ranch may use in their operation.

- Output corporation stock. Investing in output firms included purchasing shares of stock of those firms that purchase and/or process products pro- duced on the ranch. Five firms were selected as ranch input firms; $20 \%$ of available cash was invested in each input firm. Five firms were selected as ranch output firms. And $20 \%$ of available cash was invested in each output firm for each ranch model.

- Input/output stock. Investments in the selected input and output firms; thus, $10 \%$ of investable cash was used to purchase stock in each of the 10 firms for each ranch model. Table 3 lists each of the input and output firms used for the ranch models.

Table 2. Efficient Set (1989-2001)

\begin{tabular}{|c|c|c|c|c|}
\hline Firm & Symbol & Mean return & $\begin{array}{l}\text { Standard } \\
\text { deviation of } \\
\text { returns }\end{array}$ & Beta \\
\hline McCormick \& Co. & $\mathrm{MKC}$ & $10.0 \%$ & $4.3 \%$ & 0.50 \\
\hline Wrigley Co. & WWY & $15.6 \%$ & $4.7 \%$ & 0.75 \\
\hline Winn-Dixie Stores & WIN & $4.9 \%$ & $3.7 \%$ & 0.75 \\
\hline Merck \& Co. & MRK & $28.9 \%$ & $10.3 \%$ & 0.95 \\
\hline Pfizer, Inc. & PFE & $18.6 \%$ & $5.4 \%$ & 0.95 \\
\hline
\end{tabular}


Table 3. Input and Output Stocks (1989-2001)

\begin{tabular}{|c|c|c|c|c|c|}
\hline & Firm & Symbol & Mean return & $\begin{array}{l}\text { Standard } \\
\text { deviation of } \\
\text { returns }\end{array}$ & Beta \\
\hline \multirow[t]{5}{*}{ Input } & Lilly (Eli) \& Co. & LLY & $19.8 \%$ & $11.1 \%$ & 0.85 \\
\hline & Merck \& Co. & MRK & $28.9 \%$ & $10.3 \%$ & 0.95 \\
\hline & Pfizer, Inc. & PFE & $18.6 \%$ & $5.4 \%$ & 0.95 \\
\hline & Union Planter Corp. & UPC & $10.1 \%$ & $11.9 \%$ & 1.00 \\
\hline & Wells Fargo Corp. & WFC & $20.4 \%$ & $10.8 \%$ & 1.10 \\
\hline \multirow[t]{5}{*}{ Output } & Campbell Soup & $\mathrm{CPB}$ & $8.8 \%$ & $7.5 \%$ & 0.65 \\
\hline & Hormel Foods & HRL & $6.8 \%$ & $5.2 \%$ & 0.55 \\
\hline & Pilgrim's Pride Corp. & $\mathrm{CHX}$ & $11.5 \%$ & $15.3 \%$ & 0.70 \\
\hline & Smithfield Foods Inc. & SFD & $14.0 \%$ & $20.8 \%$ & 0.90 \\
\hline & Tyson Foods Inc. & TSN & $9.9 \%$ & $13.1 \%$ & 0.80 \\
\hline
\end{tabular}

\section{Findings}

Before evaluating each strategy at different debt levels, it was necessary to determine the maximum debt load that each ranch model could sustain. Only 1 of the 5 ranch models could sustain any debt load at all.

The Northeastern extra large cow/calf ranch had a maximum debt load of $11.5 \%$ (ie, maximum debt equals $11.5 \%$ of total assets). The results of the 9 financial strategies tested are summarized in Table 4. Beginning owner's equity was $\$ 2,435,500$. No ending short-term operating loans were required; therefore, there were no ending liabilities for any of the strategies. Investing in input stocks was the best strategy since 2 of the chosen ranch input stocks were included in the efficient set. Retaining all cash resulted in the smallest ending portfolio value for the model. The percentage in portfolio growth excluded the value of land appreciation.

\section{Summary and Conclusions}

The objective of this study was to evaluate the possibilities and effects of alternative financial investments for selected New Mexico ranches with various production enterprises, specifically, using excess cash generated from each ranch for several financial investment strategies and determining each strategy's effect on portfolio value. This study did not suggest that producers sell any ranch assets and use the proceeds to invest in any particular mar- ket. Rather, this study considered the opportunities and possibilities to increase the entire portfolio value by investing excess cash (beyond operating and family living requirements) into different markets or using excess cash to pay down ranch debt beyond obligation. This involved developing mixedasset portfolios by combining agricultural real estate with purely financial assets. Those financial assets included shares of a money market fund, a mutual fund, and several publicly traded agricultural firms.

Before evaluating alternative investment strategies for each ranch model, it was necessary to determine if each ranch could cash flow. Four of the 5 selected ranch models could not cash flow at any debt level over the entire period of the analysis without outside income. The largest liability for any rancher is the principal on the land purchase. Since land is an appreciating asset, it can be sold for more that what it was purchased for. Accordingly, the appreciating nature of land is valued into its price, and it is not surprising that these ranches could not cash flow since the rate of return earned on the ranch assets was less than the cost of capital to purchase them. Oltmans (1995) concludes that farmland will not and should not pay for itself if priced correctly in a competitive market and says that "the inability of farmland to generate sufficient cash flow to fully service the cost of capital investment required for its purchase is the normal competitive situation." 
Table 4. Northeast (Extra large) Cow/Calf: Select Balance Sheet Values

\begin{tabular}{|c|c|c|c|c|c|c|}
\hline Strategy & $\begin{array}{l}\text { Ending owner's } \\
\text { equity }\end{array}$ & $\begin{array}{l}\text { Ending debt/ } \\
\text { asset ratio }\end{array}$ & \multicolumn{2}{|c|}{ Ranch portfolio beta } & $\begin{array}{l}\text { Portfolio } \\
\text { growth }\end{array}$ & Rank \\
\hline & & & Cash & Market & & \\
\hline Repay debt & $\$ 3,084,000$ & 0.00 & -0.005 & 0.023 & $12.2 \%$ & 8 \\
\hline Retain cash & $\$ 3,084,000$ & 0.00 & -0.005 & 0.023 & $12.2 \%$ & 9 \\
\hline Money market & $\$ 3,173,000$ & 0.00 & -0.005 & 0.024 & $15.9 \%$ & 7 \\
\hline Mutual fund & $\$ 3,231,000$ & 0.00 & -0.005 & 0.023 & $18.2 \%$ & 6 \\
\hline Naive portfolio & $\$ 3,363,000$ & 0.00 & -0.006 & 0.023 & $23.6 \%$ & 5 \\
\hline Efficient portfolio & $\$ 3,814,000$ & 0.00 & -0.008 & 0.020 & $42.2 \%$ & 2 \\
\hline Input stocks & $\$ 4,192,000$ & 0.00 & -0.010 & 0.019 & $57.7 \%$ & 1 \\
\hline Output stocks & $\$ 3,409,000$ & 0.00 & -0.005 & 0.023 & $25.5 \%$ & 4 \\
\hline Input/output stocks & $\$ 3,764,000$ & 0.00 & -0.008 & 0.021 & $40.1 \%$ & 3 \\
\hline
\end{tabular}

For the ranch model that could cash flow, investing in the input firm stocks had the greatest effect on portfolio value. The efficient set had the next greatest effect on ending portfolio value. This is not surprising since modern portfolio theory says that the efficient set is the optimal set for a given level of risk and return. Retaining all cash resulted in the lowest ending portfolio value for the ranch model, while paying down debt resulted in the lowest ending debt-to-asset ratio. This suggests that ranchers could benefit (increase owner's equity) from investing in financial assets and/or paying down their debt liability.

Although ranchers may increase their portfolio value by investing in financial assets, there is no evidence to suggest that investing in agricultural companies provides credible diversification benefits to ranchers. The low income correlation between the ranch portfolios and the S\&P 500 led to extremely small beta coefficients. Almost every calculated beta coefficient (cash or market) was virtually zero or very close to zero. These small beta coefficients suggest there was no clear relationship between the ranch portfolio returns and market returns. While this paper provides a mechanism to test financial strategies, it is only a beginning. We need to continue to search for a financial strategy that will represent true financial diversification for a ranch.
Authors are college assistant professor, professor, and former research specialist, New Mexico State University, Department of Agricultural Economics and Agricultural Business. This work was supported by the New Mexico Agricultural Experiment Station and the New Mexico Range Improvement Task Force.

\section{References}

Brigham, E. F., AND M. C. EhrhardT. 2002. Financial management: theory and practice. 10th ed. Thompson Learning, Inc.

Libbin, J. D., J. Kohler, And J. M. Hawkes. 2004. Does modern portfolio theory apply to agricultural land ownership? Concepts for farmers and farm managers. Journal of the American Society of Farm Managers and Rural Appraisers 67(1):85-96.

Markowitz, H. M. 1959. Portfolio selection: Efficient diversification of investments. New Haven, CT: Yale University Press.

Oltmans, A. W. 1995. Why farmland cannot, will not and should not pay for itself. Journal of the American Society of Farm Managers and Rural Appraisers 59(1):57-67.

Sharpe, W. F. 1970. Portfolio theory and capital markets. New York, NY: McGraw-Hill.

Torell L. A., J. M. Hawkes, And S. A. Bailey. 2000. Range livestock cost and return estimates for New Mexico, 1997. Las Cruces, NM: New Mexico State University. Agricultural Experiment Station Research Report 738.

VALUE LINE INVESTMENT SURVEY. 1989-2002. Various issues. New York, NY: Value Line. 